\title{
繰返し面内せん断力を受ける波形鋼板パネルの弾塑性変形挙動 ELASTO-PLASTIC DEFORMATION BEHAVIOR OF CORRUGATED STEEL DIAPHRAGM UNDER CYCLIC SHEAR LOAD
}

\author{
清 水 信 孝*, 岡田忠 義**, 五十嵐規矩夫*** \\ Nobutaka SHIMIZU, Tadayoshi OKADA and Kikuo IKARASHI
}

\begin{abstract}
Shear panel tests on corrugated steel diaphragms were carried out to examine elasto-plastic deformation behavior due to end failure action and tension field action under cyclic loading. Based on the test results, two types of elasto-plastic hysteresis model were proposed for each action. The hysteresis of end failure action was modeled as a bi-linear curve based on initial stiffness and end failure strength. Furthermore, the hysteresis of tension field action was modeled as a curve based on initial stiffness, load decreasing stiffness, tension field strength, and slip strength. Each hysteresis model provided appropriate estimation of energy dissipation for the test results.
\end{abstract}

Keywords : Corrugated steel plate, Shear strength, Shear stiffness, Elasto-plastic deformation, Hysteresis model 波形鋼板, せん断耐力, せん断岡性, 弾塑性変形, 履歴モデル

1. はじめに

波形鋼板は主として面外力に抵抗する材として建築構造物の屋根 や壁に利用されているが，面内せん断力に対する優れた抵抗特性を 活用した構法一の適用も試みられている.これらの例として, 面内 せん断力に対する波形鋼板の弾性抵抗を利用することで水平ブレー スを省略した屋根 ${ }^{1)}{ }^{2}$, 波形鋼板の板要素をせん断降伏させることで 繰返し地震力に対しエネルギー吸収する耐震壁 ${ }^{3)}$, 4), 波形鋼板周囲の ビス接合部の支圧破壊で面内せん断力に対しエネルギー吸収する耐 力壁 5), 6) や屋根 ${ }^{7)}$ などが挙げられる.

これらの構法では, (1)弾性的な応答性状を得るために全ての抵抗 要素を降伏させず弾性範囲に留める, (2)エネルギー吸収性能を発揮 させるために特定の抵抗要素を降伏させる, の何れかの設計手法が 採られる.ここで, 波形鋼板に起こり得る崩壊モード: 波形鋼板全 体のせん断座屈 ${ }^{8), 9)}$, 板要素の局部せん断座屈, 板要素のせん断降伏, 波形鋼板山部の端部崩壊 $\left.{ }^{10)}, 11\right)$, 波形鋼板周囲のビス接合部の支圧破 壊 ${ }^{12)}{ }^{13)}$ は, 波形鋼板の幾何形状, 素材強度, パネル周囲の接合条件 などにより制御される.

各崩壊モードの耐力の評価については, 既往の研究成果により設 計技術が概水整備された状況にある。一方, エネルギー吸収性能の 評価については, 板要素のせん断降伏およびビス接合部の支圧破壊
に関する繰返し変形挙動が実験的に明らかにされるに留まり，その 他の崩壊モードが発現する場合の繰返し变形挙動に関する研究はほ とんど見られない.

このような状況を踏まえ，筆者等は，波形鋼板の幾何学的な特徵 に起因する二つの崩壊モード : パネルの山部に生じる端部崩壊 ${ }^{11}$, パネル全体がせん断座屈した後に生じる張力場 ${ }^{14)}$ の基礎的な変形性 状を把握するための単調載荷試験を実施した。ここでは, 波形鋼板 パネルの断面形状がせん断抵抗特性に与える影響を明らかにし，断 面形状の設計により剛性と耐力を制御することで，耐力劣化を抑え た安定的な弾塑性変形性状が得られることを確認している。この単 調載荷試験に基づく知見を, 繰返し変形挙動の性能評価に展開する ことで，エネルギー吸収材としての波形鋼板の可能性がさらに拡が るものと考える.

本研究では, 波形鋼板の端部崩壊挙動および張力場挙動に焦点を 当て, 載荷履歴とパネル断面形状を実験変数としたパネルせん断試 験により, 繰返し面内せん断力に対する波形鋼板パネルの弾塑性変 形挙動を明らかにする。単調載荷試験に基づき導出した剛性式 ${ }^{11), 15)}$ および耐力式 ${ }^{11,14)}$ の繰返し変形挙動に対する適用性を検証した後, これらの式に基づく履歴モデルを提案し, エネルギー吸収性能の評 価を試みる。
* 新日本製鐵鋼構造研究開発センター 主任研究員·工修 東京工業大学大学院理工学研究科建築学専攻 博士後期課程 (社会人コース)

** 新日本製鐵鋼構造研究開発センター 主幹研究員・工博

*** 東京工業大学大学院理工学研究科建築学専攻 准教授・博士 (工学)
Senior Researcher, Steel Structure Development Center, Nippon Steel, M. Eng. Graduate Student, Dept. of Arch. and Building Eng., Tokyo Institute of Technology

Chief Researcher, Steel Structure Development Center, Nippon Steel, Dr. Eng. Assoc. Prof., Dept. of Arch. and Building Eng., Tokyo Institute of Technology, Dr. Eng. 


\section{2. 単調載荷試験で確認した波形鋼板の基礎的な変形性状}

単調載荷試験における波形鋼板パネルの端部崩壊挙動および張力 場挙動の基礎的な変形性状として, 文献 11 および文献 14 の研究で 得られたせん断力 $P$ 一せん断変形角 $\gamma$ 関係を図 1 ( a) および図 1 (b) にそれぞれ示す。ここで, 図 1 (a) 中の記号は, $K$ : 初期剛性, $P_{y}$ : 降伏耐力, $e^{P} P_{\text {max }}$ : 最大耐力を表す（図 5(d) の定義に対応）.また, 図 1 (b) 中の記号は, $e_{e} K$ : 初期剛性, $e_{e}$ : 弾性座屈耐力, $e_{p}$ : 後座屈 耐力， $P_{t}$ : 張力場耐力を表す (図 6 (d) の定義に対応) 注1). パネル試 験体は, サイズが幅 $800 \mathrm{~mm} \times$ 長さ $800 \mathrm{~mm}$, 板厚が $t=0.4 \mathrm{~mm}$ の波形鋼板 からなり，断面形状は図 2 に示寸寸法記号による.

図 1 (a) は，山ピッチ $q=80 \mathrm{~mm}$, 山高さ $h=20 \mathrm{~mm}$ とし, 上フランジ幅 $f$ を $0,15,25,40 \mathrm{~mm}$ と変化させた場合（図 $2(\mathrm{a})$ ) の，端部崩壊挙 動の $P-\gamma$ 関係である.これは, 山部の断面が弾性的にゆがむ変形を 伴う載荷初期の線形域から, 断面が倒れ込みながら降伏するスウェ イのモードによる端部崩壊の形成過程に移行し, 徐々に剛性を低下 して最大耐力に到達した後に耐力劣化する, という変形性状により 特徵付けられる ${ }^{11}$. 剛性, 耐力, 耐力劣化の程度は, 上フランジ幅 $f$ に影響され, $f$ が小さいほど, 初期剛性, 降伏耐力, 最大耐力が上 昇するが, 最大耐力到達後の耐力劣化が著しくなる傾向を示してい る。一方， $f$ が大きいほど，剛性，耐力は低下寸るが，耐力劣化は抑 えられている. 特に, $f=40 \mathrm{~mm}$ とした長方形断面のケースでは, 劣化 後の耐力が $P_{e} P_{y}$ より大きな荷重域に留まり, 耐力劣化が抑制された安 定的な弾塑性変形挙動を示している。

図 1 (b) は, 山ピッチ $q=40 \mathrm{~mm}$, 上フランジ幅 $f=20 \mathrm{~mm}$ とし, 山高さ $h$ を $5,7,10 \mathrm{~mm}$ と変化させた場合 (図 $2(\mathrm{~b})$ ) の, 張力場挙動の $P-\gamma$ 関係である。これは, 載荷初期の線形性がせん断座屈により失われ, 後座屈耐力まで耐力上昇した後に耐力劣化し, 座屈波形のしわに沿 い波形鋼板が引き伸ばされる張力場の形成により再び耐力上昇して いく, という変形性状により特徴付けられる ${ }^{14)}$. 耐力劣化と耐力上 昇の程度には, 後座屈耐力と張力場耐力の相対的な大小関係による 変化が見られる.$h$ が大きいと $(h=10 \mathrm{~mm})$, 後座屈耐力が張力場耐力 より大きくなり，後座屈耐力から張力場耐力への移行に伴う耐力劣 化が著しくなる，一方， $h$ が小さくなり $(h=7 \mathrm{~mm})$, 後座屈耐力が張 力場耐力の大きさに近づくと, 耐力劣化は抑制される。さらに $h$ が 小さくなると $(h=5 \mathrm{~mm})$, より耐力劣化は抑えられるが, 張力場挙動 に移行後の変形の進展に伴う耐力上昇が顕著となっている.

以上のように，単調載荷に対しては，端部崩壊挙動および張力場 挙動ともに, 波形鋼板パネルの断面形状により, 剛性, 耐力, 耐力 劣化および而力上昇の程度を制御できることを確認している．端部 崩壊挙動では，山部の断面を長方形と寸ることで，耐力劣化を抑え た安定的な弾塑性変形挙動を得ることができる. また, 張力場挙動 では，山高さの設定により後座屈耐力を張力場耐力の大きさに近づ けることで，座屈後の耐力劣化および変形進展時の耐力上昇を抑え ることができる.これらの知見を参考に, 繰返し変形挙動の調查に 向けたせん断試験を計画した。

\section{3. 繰返し履歴特性の把握に向けた波形鋼板パネルせん断試験}

崩壊モードに応じた二つのシリーズからなる試験体の一覧を表 1 に示す. 端部崩壊挙動の調查を目的とするシリーズ I では, 単調載 荷試験（図 1 (a)) で安定的な弾塑性変形挙動を示した長方形断面 (図

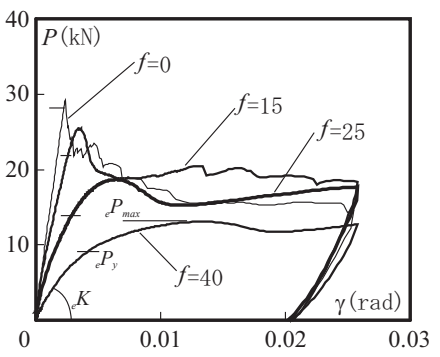

(a) 端部崩壊挙動 ${ }^{11}$

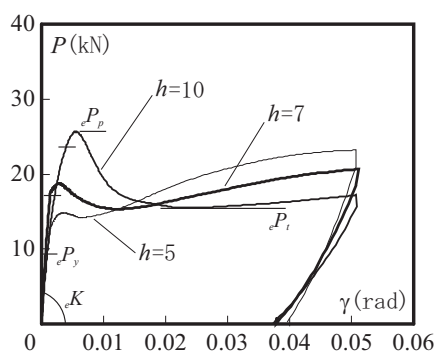

(b) 張力場挙動 ${ }^{14)}$
図 1 単調載荷試験のせん断力 $P$-せん断変形角 $\gamma$ 関係

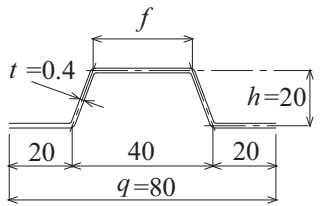

(a) 端部崩壊挙動 ${ }^{11}$

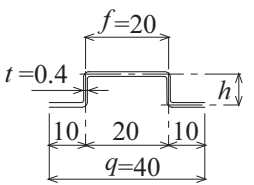

(b) 張力場挙動 ${ }^{14)}$
図 2 単調載荷試験のパネル断面形状

表 1 試験体一覧

\begin{tabular}{|c|c|c|c|c|c|c|c|c|c|c|c|}
\hline & \multirow[b]{2}{*}{ 試験体 } & \multicolumn{9}{|c|}{ パネル形状 } & \multirow{2}{*}{$\begin{array}{l}\text { 載荷 } \\
\text { 履歴 }\end{array}$} \\
\hline & & $\begin{array}{c}a \\
(\mathrm{~mm})\end{array}$ & $\begin{array}{c}b \\
(\mathrm{~mm})\end{array}$ & $\begin{array}{c}t \\
(\mathrm{~mm})\end{array}$ & $\begin{array}{c}q \\
(\mathrm{~mm})\end{array}$ & $\begin{array}{c}f \\
(\mathrm{~mm})\end{array}$ & \begin{tabular}{|c|}
$e$ \\
$(\mathrm{~mm})$ \\
\end{tabular} & $\begin{array}{c}g \\
(\mathrm{~mm})\end{array}$ & $\begin{array}{c}l \\
(\mathrm{~mm})\end{array}$ & $\begin{array}{c}h \\
(\mathrm{~mm}) \\
\end{array}$ & \\
\hline \multirow{5}{*}{ I } & E-h20-f40-M & 800 & 800 & 0.55 & 80 & 40 & 20 & 0 & 40 & 20 & 単調 \\
\hline & E-h20-f40-C & 800 & 800 & 0.55 & 80 & 40 & 20 & 0 & 40 & 20 & 繰返し \\
\hline & E-h20-f25-M & 800 & 800 & 0.55 & 80 & 25 & 20 & 7.5 & 40 & 20 & 単調 \\
\hline & E-h20-f25-C & 800 & 800 & 0.55 & 80 & 25 & 20 & 7.5 & 40 & 20 & 繰返し \\
\hline & E-h15-f40-C & 800 & 800 & 0.55 & 80 & 40 & 20 & 0 & 40 & 15 & 繰返し \\
\hline \multirow{6}{*}{ II } & T-h10-f20-M & 800 & 800 & 0.55 & 40 & 20 & 10 & 0 & 20 & 10 & 単調 \\
\hline & $\mathrm{T}-\mathrm{h} 10-\mathrm{f} 20-\mathrm{C}$ & 800 & 800 & 0.55 & 40 & 20 & 10 & 0 & 20 & 10 & 繰返し \\
\hline & $\mathrm{T}-\mathrm{h} 7-\mathrm{f} 20-\mathrm{M}$ & 800 & 800 & 0.55 & 40 & 20 & 10 & 0 & 20 & 7 & 単調 \\
\hline & $\mathrm{T}-\mathrm{h} 7-\mathrm{f} 20-\mathrm{C}$ & 800 & 800 & 0.55 & 40 & 20 & 10 & 0 & 20 & 7 & 繰返し \\
\hline & $\mathrm{T}-\mathrm{h} 5-\mathrm{f} 20-\mathrm{M}$ & 800 & 800 & 0.55 & 40 & 20 & 10 & 0 & 20 & 5 & 単調 \\
\hline & $\mathrm{T}-\mathrm{h} 5-\mathrm{f} 20-\mathrm{C}$ & 800 & 800 & 0.55 & 40 & 20 & 10 & 0 & 20 & 5 & 繰返し \\
\hline
\end{tabular}

表 2 試験体の予想耐力

\begin{tabular}{|c|c|c|c|c|c|c|c|c|c|}
\hline \multirow{2}{*}{\multicolumn{2}{|c|}{ 試験体 }} & 降伏 & \multicolumn{2}{|c|}{ 端部崩壊 } & \multicolumn{3}{|c|}{ せん断座屈 } & \multirow{2}{*}{\begin{tabular}{|c} 
張力場 \\
$\begin{array}{c}{ }^{2} P_{t} \\
(\mathrm{kN})\end{array}$
\end{tabular}} & \multirow{2}{*}{$\frac{\text { 耐力比 }^{\frac{c P_{c r} 3}{P_{P}}}}{4}$} \\
\hline & & $\begin{array}{l}{ }_{c} P_{\tau y} \\
(\mathrm{kN})\end{array}$ & $\begin{array}{l}{ }_{c} P_{1 y} \\
(\mathrm{kN})\end{array}$ & $\begin{array}{l}{ }_{c} P_{1} \\
(\mathrm{kN})\end{array}$ & $\begin{array}{c}{ }_{c} P_{c r 1} 1 \\
(\mathrm{kN})\end{array}$ & $\begin{array}{c}{ }_{c} P_{c r 2} \\
(\mathrm{kN})\end{array}$ & $\begin{array}{c}{ }_{c} P_{c r} 3 \\
(\mathrm{kN})\end{array}$ & & \\
\hline & E-h20-f40-M/C & 86.6 & 13.8 & 20.6 & 122.1 & 145.2 & 74.0 & - & - \\
\hline I & E-h20-f25-M/C & 86.6 & 28.6 & 42.9 & 109.2 & 132.4 & 72.7 & - & - \\
\hline & E-h15-f40-C & 86.6 & 18.3 & 27.5 & 78.9 & 129.6 & 72.4 & - & - \\
\hline & T-h10-f20-M/C & 86.6 & 55.0 & 82.5 & 42.8 & 46.2 & 46.1 & 27.7 & 0.60 \\
\hline & $\mathrm{T}-\mathrm{h} 7-\mathrm{f} 20-\mathrm{M} / \mathrm{C}$ & 86.6 & 78.6 & 117.9 & 24.9 & 24.3 & 32.5 & 30.6 & 0.94 \\
\hline & T-h5-f20-M/C & 86.6 & 110.0 & 165.0 & 15.0 & 13.5 & 24.3 & 34.1 & 1.40 \\
\hline
\end{tabular}

表 3 鋼材の機械的性質

\begin{tabular}{|c|c|c|c|c|c|c|}
\hline $\begin{array}{c}\text { 板全厚 } \\
(\mathrm{mm})\end{array}$ & $\begin{array}{c}\text { めっき厚 } \\
(\mathrm{mm})\end{array}$ & $\begin{array}{c}\text { 鋼板厚 } \\
(\mathrm{mm})\end{array}$ & $\begin{array}{c}\text { 降伏点 } \\
\left(\mathrm{N} / \mathrm{mm}^{2}\right)\end{array}$ & $\begin{array}{c}\text { 引張強さ } \\
\left(\mathrm{N} / \mathrm{mm}^{2}\right)\end{array}$ & $\begin{array}{c}\text { 破断伸び } \\
(\%)\end{array}$ & $\begin{array}{c}\text { 試験片 } \\
\text { 規格 }\end{array}$ \\
\hline 0.60 & 0.05 & 0.55 & 341 & 480 & 33.2 & JIS5 \\
\hline
\end{tabular}

2 (a) において $f=40 \mathrm{~mm}$ ) に近い断面形状を基本に，山高さ $h$ と上フラ ンジ幅 $f$ の断面変化, 載荷履歴（繰返し有無）を実験変数とする．張 力場挙動の調査を目的とするシリーズ II では, 単調載荷試験（図 1(b)）で座屈後の耐力劣化と変形進展時の耐力上昇の抑制に有効で あった断形状（図 $2(\mathrm{~b})$ において $h=7 \mathrm{~mm}$ ) を基本に，山高さ $h$ の断面 変化，載荷履歴（繰返し有無）を実験変数とする.

表 1 中の記号は, 図 3 (a) 〜 (b) に示す試験体パネルの寸法記号に 対応する .ここで, $a$ : パネル幅, $b$ : パネル長さ, $q$ : 山ピッチ, $h$ : 山高さ, $t$ : 板厚, $e$ :下フランジ幅の $1 / 2$ ( $2 e$ が下フランジ幅に相当), $f$ : 上フランジ幅, $g$ : ウェブの投影幅, $l$ : 上フランジ幅とウェブ投影 
幅の和を表す. 試験体名称の記号は, 頭文字が想定する崩壊モード (E: 端部崩壊, $\mathrm{T}$ : 張力場 $), \mathrm{h}$ 以下の数值が山高さ, $\mathrm{f}$ 以下の数值が上フ ランジ幅, 末尾のハイフン以下の文字が載荷履歴（M: 単調, C: 繰返し) を表す。

シリーズ I では， $q=80 \mathrm{~mm} ， e=20 \mathrm{~mm}$ を共通とし， $f$ を $25 ， 40 \mathrm{~mm} ， h$ を 15, $20 \mathrm{~mm}$ と変化させた. 一方, シリーズ II では, $q=40 \mathrm{~mm}, f=20 \mathrm{~mm}$, $e=10 \mathrm{~mm}$ を共通とし， $h$ を $5,7,10 \mathrm{~mm}$ と変化させた．なお，パネルの 断面形状は, 調查対象と寸る端部崩壊またはせん断座屈後の張力場 挙動を他の崩壊モードよりも先行させることを狙い設定したもので あるが，シリーズIおよびII のパネルは，一般的なキーストンプ レートの約 $1 / 1.3$ および $1 / 2.5$ ，デッキプレートの約 $1 / 3.5$ および 1/7 のスケールに，それぞれ対応している．表 2 に文献 11 および文 献 14 の各耐力式（5.1～5.2 節を参照）とせん断降伏耐力式による 耐力予測值 ${ }_{c} P_{1 y}$ : 端部崩壊の降伏耐力, ${ }_{c} P_{1}$ : 端部崩壊の最大耐力, ${ }_{c} P_{c r 1},{ }_{c} P_{c r 2}$ : せん断弾性座屈耐力, ${ }_{c} P_{c r 3}$ : 後座屈耐力, $P_{c} P_{t}$ : 張力場耐 力, $P_{\text {tv }}$ : 世ん断降伏耐力 $\left(=b \cdot t \cdot \tau_{y}, \tau_{y}\right.$ は降伏せん断応力度 $\left.)\right)$ を示寸. 各耐力予測值を比べると, シリーズ I では端部崩壊, シリーズ II で はせん断座屈および座屈後の張力場の耐力が他のモードより小さく なっている．このように耐力予測值を比較することで，波形鋼板パ ネルの崩壊モードを予測することができる.

試験体パネルは，亜鉛めっき鋼板を折り曲げ半径（内法）が 板厚と同等となるようにプレス成形して製作した。 パネル寸法 $(a=b=800 \mathrm{~mm})$ と使用した鋼板（めっき層を除き $t=0.55 \mathrm{~mm}$ ）は各試験 体で共通であり，鋼板の機械的性質および板厚実測值を表 3 に示寸.

せん断試験は, 図 4 に示寸試験装置により実施した。試験体パネ ルの下フランジ面を, 図 4(b) に示寸四隅にピン機構（自己潤滑夕 イプの軸受を設置）を設けた鋼製枠（ピン間距離を $800 \mathrm{~mm} \times 800 \mathrm{~mm}$, 枠断面を幅 $60 \mathrm{~mm} \times$ 高さ $95 \mathrm{~mm}$ の無垢材とした）の上面にボルト接合 し，図 4 (a) に示すように鋼製枠の一辺を反力床に固定した固定梁に 締結した，その対辺を載荷梁につなぎ，油圧ジャッキを用いて静的 な面内せん断力 $P$ を与え, 測定したせん断変形 $\delta$ からせん断変形角 $\gamma(=\delta / 800)$ を求めた.

載荷履歴は，単調載荷のものを除き，変位制御（ $\gamma= \pm 1 / 800$, $1 / 400 ， 1 / 200 ， 1 / 100 ， 1 / 66 ， 1 / 50 ， 1 / 40 ， 1 / 33)$ による漸増交番繰 返し載荷を正負二回づつ与えるものとした。最大変位振幅は試験体 の変形挙動を観察しながら決定し，シリーズＩ（端部崩壊挙動）の 試験体は $\gamma= \pm 1 / 40$ まで繰返し, シリーズ II（張力場挙動）の試験体 は土 $\gamma=1 / 33$ まで繰返した後に $\gamma=+1 / 20$ まで一方向に載荷した.

繰返し載荷に対するパネルのせん断変形挙動を確実に捉えるため, パネル周囲と鋼製枠の接合部は，先行降伏しないよう，パネルの下 フランジ面と鋼製枠を六角穴付きボルト M8（締め付けトルク 25Nm） で締結するボルト摩擦接合とした。ボルト頭部とパネルの間には, 図 3 (c) に示寸座金タイプの接合金物を設け，摩擦接合面の面積を確 保した。ここで，接合金物の底面形状は，下フランジの鋼製枠から の浮き上がりを抑制するよう設定し, シリーズ I では長方形（長さ (j) $34 \mathrm{~mm} \times$ 幅 $14 \mathrm{~mm}$ ）シリーズ II では円形（直径 $(j) 14 \mathrm{~mm} ）$ とした .

\section{4. 波形鋼板パネルの繰返し履歴特性}

シリーズ I およびII の各試験体について，実験観察されたパネル の変形状況を写真 1 および写真 2 に, せん断力 $P$ とせん断変形角 $\gamma$

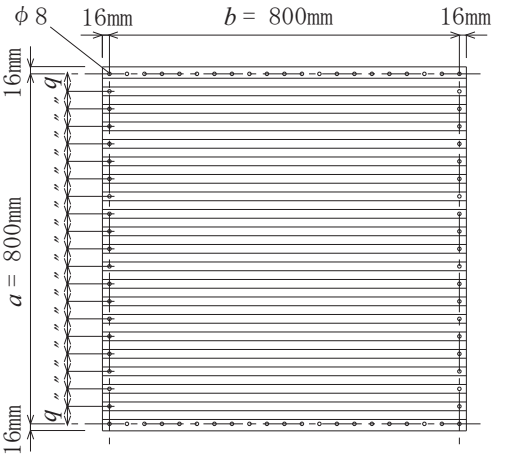

(a) 全体寸法

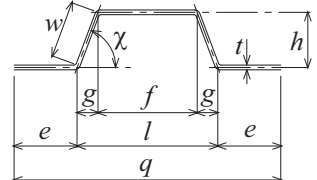

(b) 断面形状寸法 接合金物

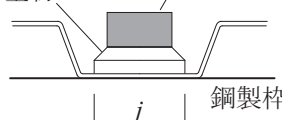

(c) パネルと枠の接合
六角孔付ボルト 18

図 3 試験体パネル

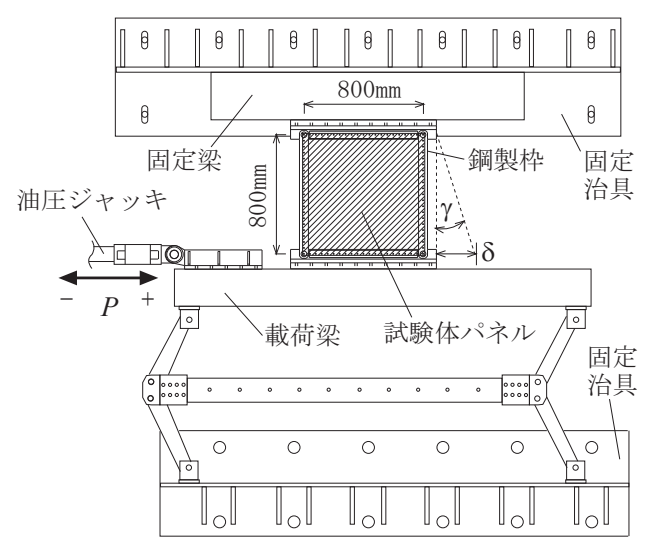

(a) 全体配置
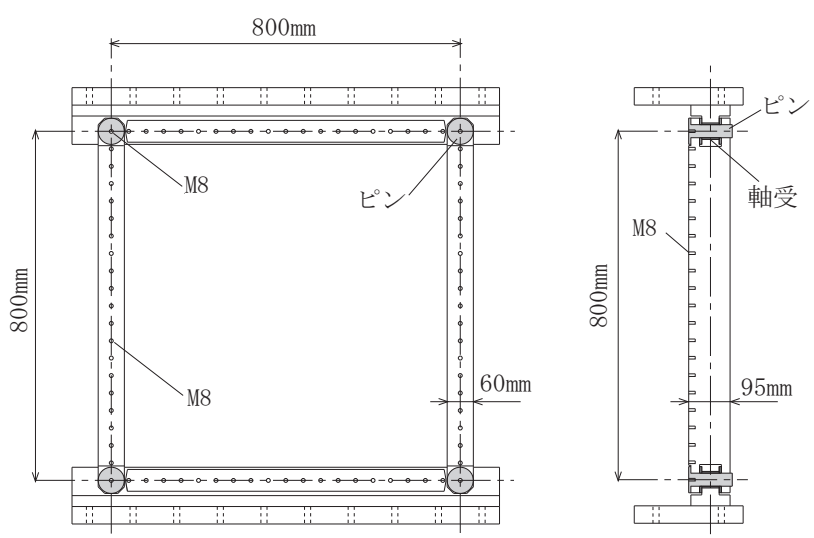

(b) 鋼製枠

図 4 試験装置

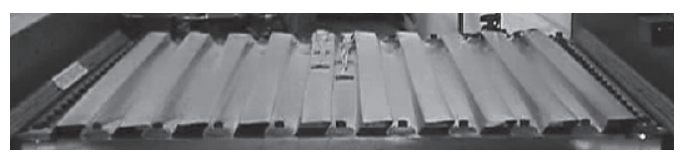

(a) $\gamma=+1 / 66$

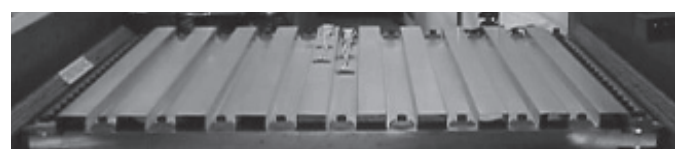

(b) $\gamma=0$

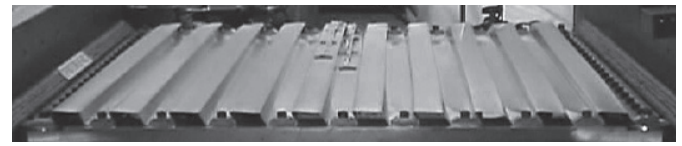

(c) $\gamma=-1 / 66$

写真 1 シリーズ I の端部崩壊挙動（E-h20-f40-C, $\gamma= \pm 1 / 66 ）$ 
の関係を図 5 および図 6 に, 図 5 (d) および図 6 (d) に基づき定義し た実験值を表 4 および表 5 にそれぞれ示す。ここで，シリーズIの 実験值は図 5 (d) に基づき, 初期剛性 ${ }_{e} K: \gamma=1 / 800$ 時の割線剛性, 最 大耐力 $e_{e} P_{\text {max }}$ : 実験で発揮された最大耐力, 降伏耐力 ${ }_{e} P_{y}:{ }_{e} P_{\text {max }}$ の点を 通り変形軸に平行に引いた直線と $K$ を示す直線との交点の変形に 対応する荷重, として定義した ${ }^{11}$. また, シリーズII の実験值は 図 6 (d) に基づき, 弾性座屈耐力 $P_{e}$ : 試験体パネル中央で測定した 鋼板表裹面の主ひずみ值に乘離が生じる荷重, 後座屈耐力 $e_{p}$ : 弾性 座屈の後に耐力上昇し耐力劣化を起こす前の頂点の荷重, 張力場耐 力 ${ }_{e} P_{t}$ : 耐力劣化後に荷重が再上昇した点の荷重, 初期剛性 ${ }_{e} K:{ }_{e} P_{y}$ の $1 / 3$ 荷重時の割線剛性, として定義した ${ }^{14)}$.

また, 実験耐力の変動を把握するため, シリーズ I の降伏耐力と 最大耐力の比 $P_{\text {max }} / P_{y}$ を表 4 に, シリーズ II の弾性座屈耐力と後座 屈耐力の比 $P_{p} / P_{e}$, 後座屈耐力と張力場耐力の比 $P_{t} /{ }_{e} P_{p}$ を表 5 に示 寸. さらに, 表 $4 \sim 5$ には, 載荷履歴の影響として, 単調載荷に対 する繰返し載荷の実験值の比も併せて示す.

\section{1 端部崩壊挙動の繰返し履歴特性}

シリーズ Iで観察された端部崩壊の代表的な変形挙動として, E-h20-f40-C の $\gamma= \pm 1 / 66$ の履歴ループにおける変形状況を写真 1 に 示寸. 載荷初期の線形域から, 山部の断面が弾性的にゆがむ波形鋼 板特有のせん断変形性状 ${ }^{15)}$ を示し, この断面のゆがみ変形が進み, 山部が倒れ込みながら降伏するスウェイのモードによる端部崩壊挙 動 ${ }^{11)}$ に移行した.この挙動は, 写真 1 (a) $\rightarrow$ 写真 $1(\mathrm{~b}) \rightarrow$ 写真 1 (c) のように, せん断力の載荷方向が逆転しても同様に繰返して発現す る.ここで, 変形の正負が切り替わる $\gamma=0$ (写真 1 (b) ) では, 山部 の断面は変形前の状態に戻っていることが確認できる.

図 5 の $P-\gamma$ 関係に示すように, 各試験体とも, 端部崩壊の進展に 伴い剛性を徐々に低下させ， $\gamma= \pm 1 / 100$ から $\gamma= \pm 1 / 66$ において最大 耐力 ${ }_{e} P_{\text {max }}$ に到達した. ここで, $e_{e} P_{\text {max }}$ に到達する変形域まで, $P-\gamma$ 関 係は紡錘形の安定した履歴ループを描いている . スウェイによる端 部崩壊の状況からさらに変形を進めると, 山部の断面が大きく倒れ 込むことでウェブが局所的に折れ曲がるクリップリングが連成し， さらに下フランジが局部座屈して局所的な張力場が形成される複合 的な抵抗モード $\left.{ }^{11}\right)$ 一移行した，変位振幅が増加すると，モードの 連成に伴い履歴ループが徐々に瘦せ細る傾向を示しているが, 載荷 を終了した $\gamma= \pm 1 / 40$ の変形域まで載荷方向が逆転しても同様のモー ドによる抵抗機構が繰返して形成され， $P-\gamma$ 関係は概衩安定した履 歴曲線を描いた。特に, 断面を長方形とした試験体（E-h20-f40-C, E-h15-f40-C) では, 変形の進展により履歴曲線が瘦せ細っても, 耐 力劣化は降伏耐力 $P_{e}$ を下回らない程度で留まっている。

載荷履歴の影響を比較するため, 図 $5(\mathrm{a}) \sim(\mathrm{b})$ に, 単調載荷と繰 返し載荷の試験結果を重初て示す。 $P_{\text {max }}$ に到達するまでは繰返し載荷 の骨格曲線と単調載荷の $P-\gamma$ 曲線は一致しており, $P_{\text {max }}$ から耐力劣 化した変形域においても繰返し載荷の $P-\gamma$ 関係の包落線は単調載荷 の $P-\gamma$ 曲線に対応している. また, 表 4 に示寸実験值の比から, 初 期剛性 $e_{e} K$, 降伏耐力 $P_{y}$, 最大耐力 $P_{e} P_{\text {max }}$ に対寸る載荷履歴の影響は小 さいことが分かる。

断面形状の影響については, 上フランジ幅 $f$ が $40 \mathrm{~mm}$ から $25 \mathrm{~mm}$ と 狭くなると, $e_{e} K, e_{e} P_{y}, e_{e} P_{\text {max }}$ が増加する一方で, $e_{e} P_{\text {max }}$ からの耐力劣化 が生じる履歴ループの変位振幅が $\gamma= \pm 1 / 66 \mathrm{rad}$ から $1 / 100 \mathrm{rad}$ と小

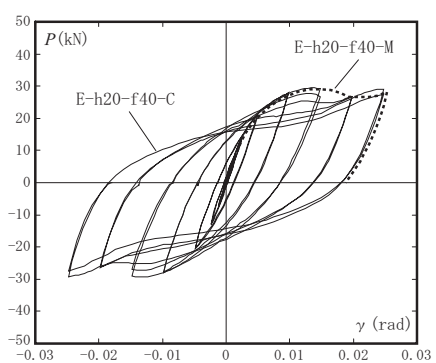

(a) $\mathrm{E}-\mathrm{h} 20-\mathrm{f} 40-\mathrm{M} / \mathrm{C}$

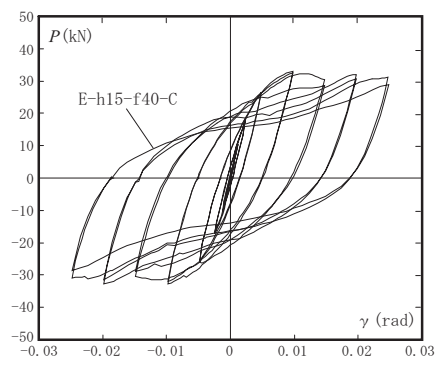

(c) $\mathrm{E}-\mathrm{h} 15-\mathrm{f} 40-\mathrm{C}$

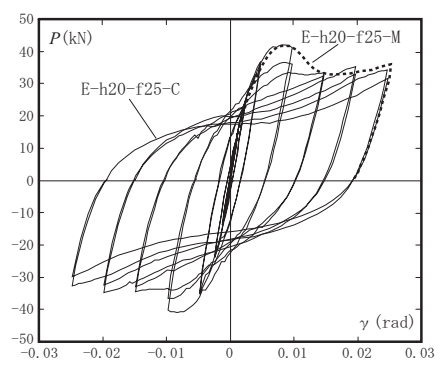

(b) $\mathrm{E}-\mathrm{h} 20-\mathrm{f} 25-\mathrm{M} / \mathrm{C}$

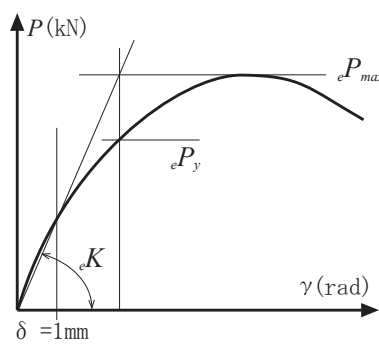

（d）実験值定義
図 5 せん断力 $P$-せん断変形角 $\gamma$ 関係 (シリーズ I)

表 4 実験結果（シリーズ I）

\begin{tabular}{|c|c|c|c|c|c|c|c|c|}
\hline \multirow{2}{*}{\multicolumn{2}{|c|}{ 試験体 }} & \multicolumn{3}{|c|}{ 実験值 } & \multirow{2}{*}{$\frac{\text { 而力変化 }}{\frac{{ }_{e} P_{\text {max }}}{{ }_{e} P_{y}}}$} & \multicolumn{3}{|c|}{ 単調と繰返しの比 } \\
\hline & & $\mid \begin{array}{c}e K \\
e K / \mathrm{kad})\end{array}$ & $\begin{array}{l}e P_{y} \\
(\mathrm{kN})\end{array}$ & $\begin{array}{c}{ }_{e} P_{\max } \\
(\mathrm{kN})\end{array}$ & & $\begin{array}{l}e K \\
\text { 比 }\end{array}$ & $\begin{array}{c}e P y \\
\text { 比 }\end{array}$ & $\begin{array}{c}e P_{\max } \\
\text { 比 }\end{array}$ \\
\hline & E-h20-f40-M & 6050 & 20.0 & 28.9 & 1.45 & 1.00 & 1.00 & 1.00 \\
\hline & E-h20-f40-C & 6300 & 20.3 & 29.4 & 1.45 & 1.04 & 1.02 & 1.02 \\
\hline I & E-h20-f25-M & 11590 & 29.3 & 41.6 & 1.42 & 1.00 & 1.00 & 1.00 \\
\hline & E-h20-f25-C & 12420 & 30.6 & 42.0 & 1. 37 & 1.07 & 1.04 & 1.01 \\
\hline & E-h15-f40-C & 8970 & 23.0 & 32.9 & 1.43 & - & $\overline{-}$ & - \\
\hline
\end{tabular}

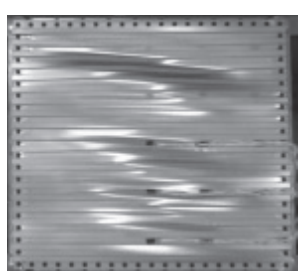

(a) $\gamma=+1 / 66$

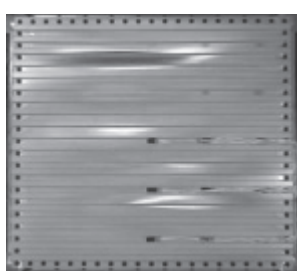

(b) $\gamma=0$

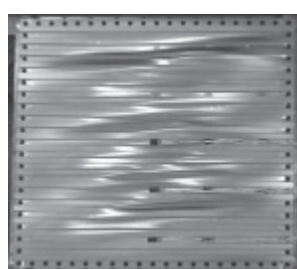

(c) $\gamma=-1 / 66$
写真 2 シリーズ II の張力場挙動 (T-h10-f20-C, $\gamma= \pm 1 / 66)$

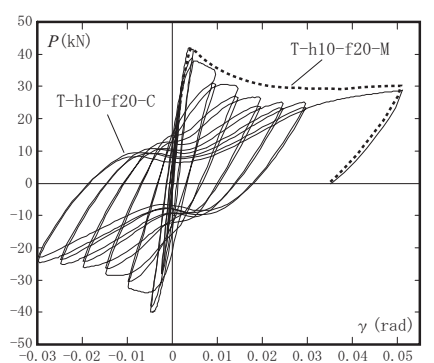

(a) $\mathrm{T}-\mathrm{h} 10-\mathrm{f} 20-\mathrm{M} / \mathrm{C}$

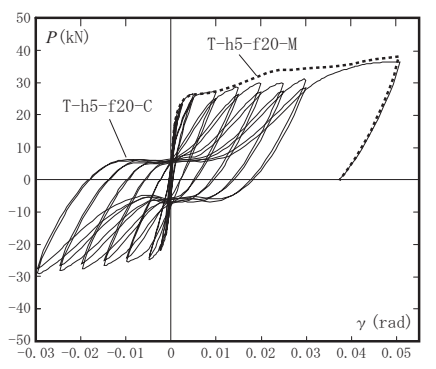

(c) $\mathrm{T}-\mathrm{h} 5-\mathrm{f} 20-\mathrm{M} / \mathrm{C}$

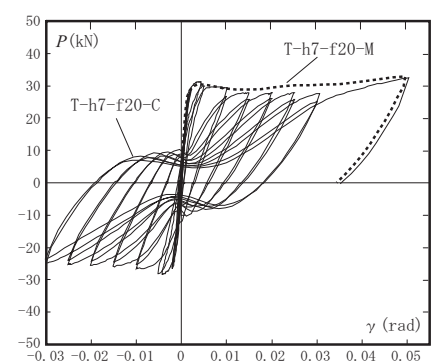

(b) $\mathrm{T}-\mathrm{h} 7-\mathrm{f} 20-\mathrm{M} / \mathrm{C}$

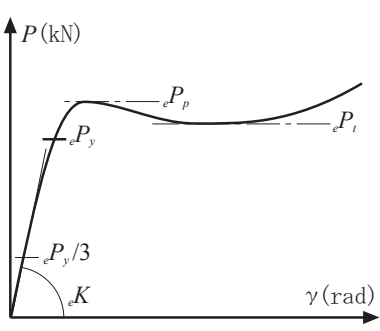

（d）実験值定義
図 6 せん断力 $P$-せん断変形角 $\gamma$ 関係（シリーズ II） 
さくなり, 履歴曲線が瘦せ細る傾向も強くなる (図 5(b)) . 一方, $f$ $=40 \mathrm{~mm}$ のまま山高さ $h$ が $20 \mathrm{~mm}$ から $15 \mathrm{~mm}$ と低くなると, $e_{e}^{K}, e_{e} P_{y}, e_{e} P_{\max }$ が増加するが, ${ }_{e} P_{\text {max }}$ からの耐力劣化が生じる変位振幅, 履歴曲線が 瘦せ細る傾向はほとんど変わらない（図 5 (c)）。これらの結果から， 端部崩壊挙動においては, 断面を長方形とし, 剛性と耐力を山高さ $h$ で設計するという手法が, 耐力劣化を抑えて瘦せ細り難い安定し た履歴曲線を得るために有効であると言える。

\section{2 張力場挙動の繰返し履歴特性}

シリーズ II で観察された張力場挙動の代表的な変形挙動として, $\mathrm{T}-\mathrm{h} 10-\mathrm{f} 20-\mathrm{C}$ の $\gamma= \pm 1 / 66$ の履歴ループにおける変形状況を写真 2 に 示寸. 載荷初期は線形的なせん断変形挙動を示し, 荷重増加により せん断座屈を発生した.さらに変形を進めると, 座屈波形のしわに 沿って波形鋼板が引き伸ばされる張力場の抵抗機構が発現した。こ の張力場挙動は, 写真 2 (a) $\rightarrow$ 写真 $2(\mathrm{~b}) \rightarrow$ 写真 2 (c) のように, せん 断力の載荷方向が逆転しても同様に繰返して発現している．ここで, 変形の正負が切り替わる $\gamma=0$ （写真 $2(\mathrm{~b})$ ) では，パネルが引き伸ば された残留変形がしわとして確認できる.

図 6 の $P-\gamma$ 関係に示すように, 各試験体とも, せん断座屈の発生 に伴い載荷初期の線形性を失い, 徐々に剛性を低下させた。弾性座 屈後の後座屈耐力への耐力上昇, 後座屈耐力からの耐力劣化の程度 には試験体により差異が見られるが，何れの試験体も, 張力場を形 成することで劣化後の耐力を再上昇している. 繰返し載荷の試験体 は, 張力場形成後に載荷方向が逆転すると, 張力場耐力より低いほ ぼ一定の耐力を維持したまま変形が進む棚状の変形領域を形成して いる.この棚状域から更に変形を進めると, ある変形角を境に棚状 部分から耐力を再び上昇させながら張力場を再形成し, 最大経験変 位点近傍で前履歴サイクルの延長線に沿って変形曲線を描いた。ま た，除荷剛性は初期剛性より小さくなる傾向が見られる.

載荷履歴の影響を比較するため, 図 $6(\mathrm{a})$ ～(c) に，単調載荷と繰 返し載荷の試験結果を重ねて示寸. 後座屈耐力 $P_{p}$ に到達するまで は繰返し載荷の骨格曲線と単調載荷の $P-\gamma$ 曲線は一致しており, 表 4 に示す実験值においても, 初期剛性 ${ }_{e} K$, 降伏耐力 $P_{e}$, 後座屈耐力 ${ }_{e} P_{p}$ に対する載荷履歴の影響は小さい, 一方, $e_{e} P_{p}$ から耐力劣化し, 張 力場を形成して耐力が再上昇寸る変形域においては, 繰返し載荷の $P-\gamma$ 関係の包落線は単調載荷の $P-\gamma$ 曲線を耐力が下回る傾向を示し ている。これは, 張力場形成による残留変形の発生により, 載荷方 向が逆転した場合に耐力上昇に要する変位量が増大寸るため, 繰返 し載荷において変位振幅を一定值で折り返すと耐力上昇が打ち切ら れたものと推察する. なお, 最終ループでは, 繰返し載荷の $P-\gamma$ 関 係の包落線は単調載荷の $P-\gamma$ 曲線に概ね到達している。このため, 表 5 に示寸繰返し載荷の張力場耐力 $P_{t}$ は, 単調載荷のものより 10 〜 20\%程度小さくなっている. また, 繰返し載荷により生じる棚 状域の耐力は，変位振幅に応じて漸減する傾向を示しており，P P の $1 / 2 \sim 1 / 5$ 程度の荷重域に対応している.

断面形状の影響については, 山高さ $h$ が大きいほど $K$ が減少し, ${ }_{e} P_{y}, e_{e} P_{p}$ が増加寸る傾向が見られるが, ${ }_{e} P_{t}$ の増減は小さい, また, 繰 返し載荷においても, $h$ による $P_{p}$ と $P_{e}$, の相対的な大小関係の変化が, 座屈後の耐力劣化および変形進展時の耐力上昇の程度に影響を与え ることが分かる $. h=10 \mathrm{~mm}$ の T-h10-f20-C では, $P_{e} P_{e} / P_{p}$ が 0.55 で後 座屈耐力から張力場耐力への移行に伴う耐力劣化が著しい. 一方, $h$
表 5 実験結果（シリーズ II）

\begin{tabular}{|c|c|c|c|c|c|c|c|c|c|c|}
\hline \multirow[b]{2}{*}{ 試験体 } & \multicolumn{4}{|c|}{ 実験值 } & \multicolumn{2}{|c|}{ 耐力変化 } & \multicolumn{4}{|c|}{ 単調と繰返しの比 } \\
\hline & $\begin{array}{c}e K \\
(\mathrm{kN} / \mathrm{rad})\end{array}$ & $\begin{array}{l}e P_{y} \\
(\mathrm{kN})\end{array}$ & $\begin{array}{l}e P_{p} \\
(\mathrm{kN})\end{array}$ & $\begin{array}{l}e P_{t} \\
(\mathrm{kN})\end{array}$ & $\frac{e P_{p}}{{ }_{e} P_{y}}$ & $\frac{e P_{t}}{{ }_{e} P_{p}}$ & $\begin{array}{l}e^{e K} \\
\text { 比 }\end{array}$ & $\begin{array}{c}e P_{y} \\
\text { 比 }\end{array}$ & $\begin{array}{c}e P_{p} \\
\text { 比 }\end{array}$ & $\begin{array}{l}e^{e} P_{t} \\
{ }^{\prime}\end{array}$ \\
\hline T-h10-f20-M & 16500 & 39.4 & 41.6 & 28.6 & 1.06 & 0.69 & 1.00 & 1.00 & 1.00 & 1.00 \\
\hline T-h10-f20-C & 17100 & 41.1 & 42.0 & 23.1 & 1.02 & 0.55 & 1.04 & 1.04 & 1.01 & 0.81 \\
\hline T-h7-f20-M & 22800 & 23.9 & 30.5 & 28.7 & 1.28 & 0.94 & 1.00 & 1.00 & 1.00 & 1.00 \\
\hline T-h7-f20-C & 23100 & 24.3 & 31.3 & 25.0 & 1.29 & 0.80 & 1.01 & 1.02 & 1.03 & 0.87 \\
\hline $\mathrm{T}-\mathrm{h} 5-\mathrm{f} 20-\mathrm{M}$ & 27100 & 11.7 & 26.5 & 26.5 & 2.26 & 1.00 & 1.00 & 1.00 & 1.00 & 1.00 \\
\hline T-h5-f20-C & 26900 & 11.5 & 27.2 & 25.1 & 2. 37 & 0.92 & 0.99 & 0.98 & 1.03 & 0.95 \\
\hline
\end{tabular}
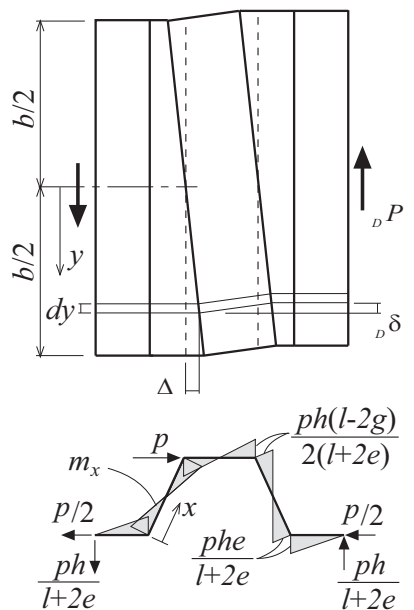

図 7 断面ゆがみ変形モデル
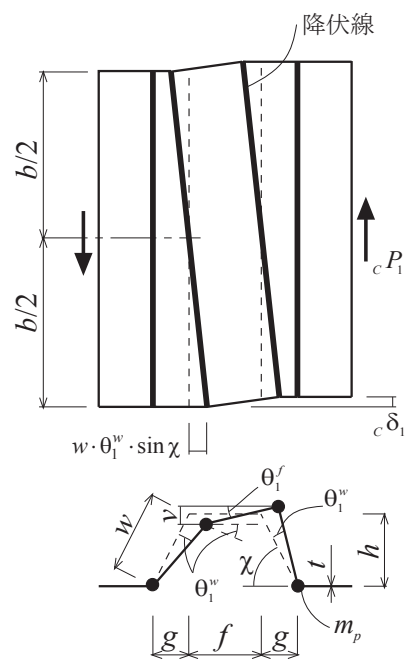

図 8 端部崩壊モデル

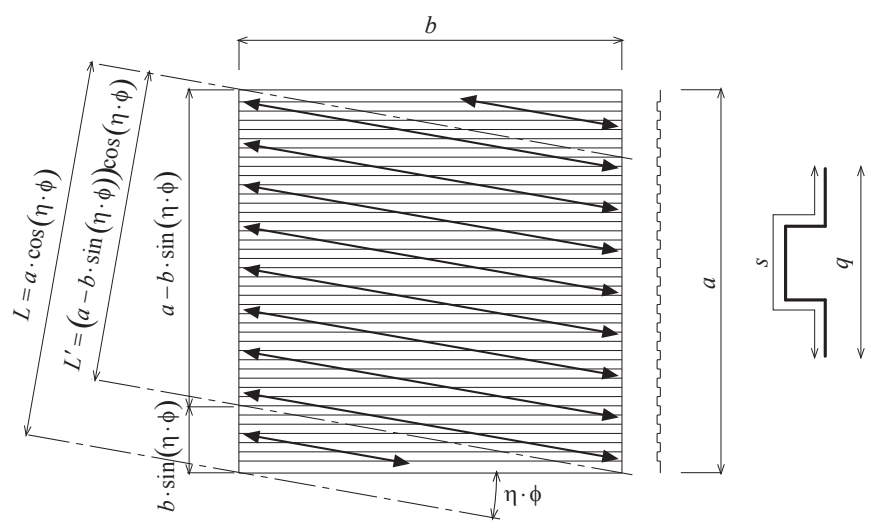

図 9 波形鋼板の張力場耐力モデル

$=7 \mathrm{~mm}$ の $\mathrm{T}-\mathrm{h} 7-\mathrm{f} 20-\mathrm{C}$ では, $e_{t} P_{t} / P_{p}$ が 0.80 と耐力劣化は抑制され，変 形の進展に伴う耐力上昇も緩やかである. $h=5 \mathrm{~mm}$ の T-h5-f20-C では, ${ }_{e} P_{t} / P_{e} P_{p}$ が 0.92 と耐力劣化は抑制されているが, 変形の進展に伴う 耐力上昇が著しい。これらの結果から, 繰返し載荷に対する張力場 挙動を制御する上でも，後座屈耐力と張力場耐力が同等になるよう に山高さ $h$ を設定するという手法が，座屈後の耐力劣化および変形 進展時の耐力上昇を抑えた履歴曲線を得るために有効であると言え る。

\section{5. 波形鋼板の繰返し履歴特性に対する初期剛性と耐力の評価}

シリーズ I（端部崩壊挙動）およびシリーズ II（張力場挙動）の 繰返し載荷試験から得られた実験值と, 単調載荷試験に基づく耐力 式 $\left.{ }^{8)}, 9\right), 11,{ }^{14)}$ および既往の剛性式 ${ }^{14)}{ }^{15}$ との対応を比較し, 各評価式 
の繰返し変形挙動に対する適用性を検証する。

\section{1 端部崩壊挙動の剛性と耐力}

面内せん断力を受ける波形鋼板の初期剛性 ${ }_{c} K$ は, 板要素の面内せ 几断剛性 ${ }_{s} K$ と, 図 7 に示す山部の断面がゆがむ変形により定まる剛 性 ${ }_{D} K$ に基づき, パネル全体の山数 $n$ を用いて次式で与える ${ }^{11}$.

$$
\begin{aligned}
& { }_{c} K=\left(\frac{1}{{ }_{D} K}+\frac{1}{{ }_{S} K}\right)^{-1} \frac{1}{n} \quad \ldots \ldots \ldots \text { (1) } \\
& { }_{s} K=\frac{b \cdot t \cdot E}{2(f+2 w+2 e)(1+v)} \\
& { }_{D} K=\frac{E \cdot t^{3} \cdot b^{3}}{144 D \cdot h^{3} \cdot f^{2}} \\
& D=\frac{8 e^{3}+8 e^{2} \cdot w-4 e \cdot f \cdot w+2 f^{2} \cdot w+f^{3}}{12 h(l+2 e)^{2}}
\end{aligned}
$$

ここで, $E$ : ヤング係数, v : ポアソン比, その他の記号は図 3 に示 すパネル各部の寸法記号に対応する .

山部が倒れ込みながら降伏するスウェイのモードによる端部崩壊 挙動の耐力 $P_{1}$ は, 図 8 に示寸崩壊モデル（図 7 の変形モデルにおい て, 山部の断面各辺で曲げモーメントが最大となる稜線部に, 塑性 モーメント $m_{p}\left(=t^{2} \cdot \sigma_{y} / 4\right)$ の降伏線ヒンジを仮定）に基づき, 次式 で与える ${ }^{11}$.

$$
{ }_{c} P_{1}=\frac{b^{2}}{f \cdot w \cdot \sin \chi}\left(1+\frac{w}{f} \cos \chi\right) m_{p}
$$

ここで，パネル各部の寸法記号は, 図 8 に示す記号に対応する .

さらに, 最大耐力に対応する式 (5) 中の塑性モーメント $m_{p}$ を降伏 モーメント $m_{v}\left(=t^{2} \cdot \sigma_{y} / 6\right)$ に置き換えることで, 降伏耐力 ${ }_{c} P_{1 v}$ を与 える次式を得る。

$$
{ }_{c} P_{1 y}=\frac{b^{2}}{f \cdot w \cdot \sin \chi}\left(1+\frac{w}{f} \cos \chi\right) m_{y}
$$

なお，図 7 の変形モデルおよび図 8 の崩壊モデルでは，上フラン ジとウェブの面が叔じれる変形を伴うが，この面の㸚じれ変形がな

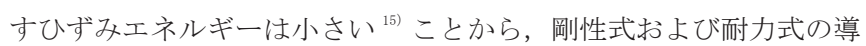
出過程では, 面のねじれ変形がなすエネルギーは考慮していない.

\section{2 張力場挙動の剛性と耐力}

せん断座屈から張力場に移行する変形挙動においても, 初期剛性 は式 (1) で表す ${ }_{c} K$ にり与える .

せん断弾性座屈耐力については, 波形鋼板を直交異方性平板と仮 定して導出した Easlay ${ }^{8}$ および五十嵐 ${ }^{9)}$ の提案する式 (7) および式 （8）それぞれの耐力式との対応を検討する.

$$
\begin{gathered}
{ }_{c} P_{c r 1}=36 r \frac{\sqrt[4]{D_{x}^{3} \cdot D_{y}}}{b^{2} \cdot t} a \cdot t \\
{ }_{c} P_{c r 2}=k_{\tau, G} \frac{\pi^{2} \cdot E}{12\left(1-v^{2}\right)}\left(\frac{t}{a}\right)^{2} a \cdot t \\
k_{\mathrm{r}, G}=5.95\left(I_{x} / I_{y}-1\right)^{0.82}+14.58 \\
\ldots \ldots
\end{gathered}
$$

\begin{tabular}{|c|c|c|c|c|c|c|c|c|c|c|c|}
\hline & \multirow[b]{2}{*}{ 試験体 } & \multicolumn{5}{|c|}{ 計算値 } & \multicolumn{5}{|c|}{ 実験値/計算値 } \\
\hline & & $\begin{array}{c}{ }^{c K} \\
(\mathrm{kN} / \mathrm{rad})\end{array}$ & $\begin{array}{c}{ }_{c} P_{c r} 1 \\
(\mathrm{kN})\end{array}$ & $\begin{array}{l}{ }_{c} P_{c r} 2 \\
(\mathrm{kN})\end{array}$ & $\begin{array}{c}{ }_{c} P_{c r}{ }^{3} \\
(\mathrm{kN})\end{array}$ & $\begin{array}{l}{ }_{c} P_{t} \\
(\mathrm{kN})\end{array}$ & $\frac{e K}{{ }_{c} K}$ & $\frac{e P_{y}}{{ }_{c} P_{c r 1}}$ & $\frac{{ }_{e} P_{y}}{{ }_{c} P_{c r 2}}$ & $\frac{e P p}{{ }_{c} P_{c r 3}}$ & $\frac{e^{e} P_{t}}{{ }_{c} P_{t}}$ \\
\hline & T-h10-f20-M & 18676 & 42.8 & 46.2 & 46. 1 & 27.7 & 0.88 & 0.92 & 0.85 & 0.90 & 1.03 \\
\hline & $\mathrm{T}-\mathrm{h} 10-\mathrm{f} 20-\mathrm{C}$ & 18676 & 42.8 & 46.2 & 46.1 & 27.7 & 0.92 & 0.96 & 0.89 & 0.91 & 0.83 \\
\hline & $\mathrm{T}-\mathrm{h} 7-\mathrm{f} 20-\mathrm{M}$ & 23010 & 24.9 & 24.3 & 32.5 & 30.6 & 0.99 & 0.96 & 0.98 & 0.94 & 0.94 \\
\hline & $\mathrm{T}-\mathrm{h} 7-\mathrm{f} 20-\mathrm{C}$ & 23010 & 24.9 & 24.3 & 32.5 & 30.6 & 1.00 & 0.98 & 1.00 & 0.96 & 0.82 \\
\hline & T-h5-f20-M & 26193 & 15.0 & 13.5 & 24.3 & 34.1 & 1.03 & 0.78 & 0.86 & 1.09 & 0.78 \\
\hline & $\mathrm{T}-\mathrm{h} 5-\mathrm{f} 20-\mathrm{C}$ & 26193 & 15.0 & 13.5 & 24.3 & 34.1 & 1.03 & 0.77 & 0.85 & 1.12 & 0.74 \\
\hline & & & & & & 平均 & 0.98 & 0.89 & 0.91 & 0.99 & 0.86 \\
\hline & & & & & & 動係数 & 0.06 & 0.10 & 0.07 & 0.09 & 0.12 \\
\hline
\end{tabular}

ここで, $r$ : パネル周囲の固定度（単純支持 1.0 , 固定支持 1.9), $D_{x}$ :

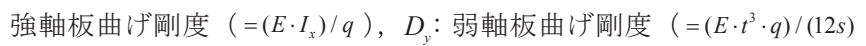
), $I_{x}$ : 山部の断面二次モーメント, $I_{x} / I_{y}$ : 曲代剛比（強軸剛性 $I_{x}$ を 弱軸剛性 $I_{y}$ で除した值）である。
表 6 実験值と計算值の対応（シリーズ I）

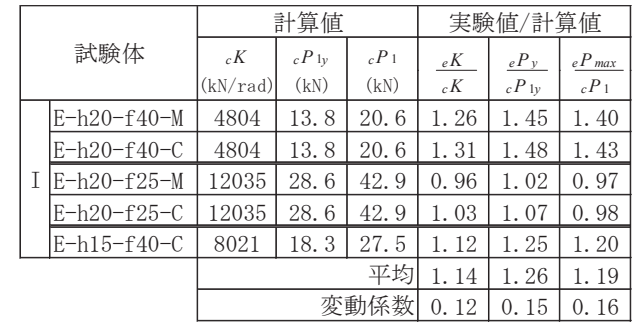

表 7 実験值と計算值の対応（シリーズ II）

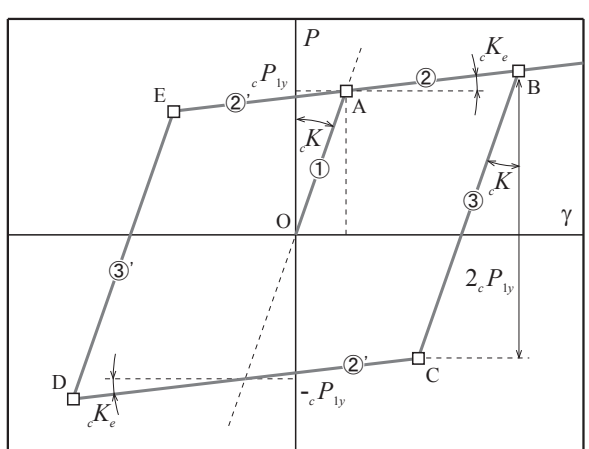

図 10 端部崩壊挙動の繰返し履歴モデル

後座屈耐力は，平板を対象とした木村 ${ }^{16)}$ の耐力式を波形鋼板に拡 張 ${ }^{14)}$ した次式で与える.

$$
\begin{aligned}
& { }_{c} P_{c r 3}=\frac{\lambda_{p}^{*}}{\lambda^{*}} \tau_{y} \cdot a \cdot t \quad\left(\lambda^{*} \geq \lambda_{e}^{*}\right) \\
& { }_{c} P_{c r 3}=\left((\alpha-1)\left(\frac{\lambda^{*}}{\lambda_{e}^{*}}\right)+1\right) \tau_{y} \cdot a \cdot t \quad\left(\lambda^{*} \leq \lambda_{e}^{*}\right)
\end{aligned}
$$

ここで, $\tau_{y}$ : 降伏せん断応力度, $\alpha$ : 降伏応力度に対する比例限応力 度の比 $(=0.5), \lambda^{*}$ : 換算幅厚比 $\left(=a / t\left(\tau_{y} /\left(k_{\tau, G} \cdot E\right)\right)^{0.5}\right), \lambda_{e}^{*}$ : 弾性限界 幅厚比 $(=0.9 / \alpha), \lambda_{p}^{*}$ : 塑性限界幅厚比 $\left(=(3 \alpha-1) \lambda_{e}^{*} /(2 \alpha)\right)$ である.

張力場耐力は, Wagner の張力場モデル ${ }^{10)}$ を拡張した図 9 に示寸波

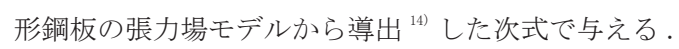

$$
{ }_{c} P_{t}=a \cdot t \cdot \frac{s}{q} \sigma_{y} \cdot \sin (\eta \cdot \phi) \cdot \cos (\eta \cdot \phi)
$$

ここで, $\phi$ はせん断弾性座屈の波形の角度を表し, 文献 8 に基づき 強軸板曲げ剛度 $D_{x}$ と弱軸板曲 げ岡度 $D_{y}$ を用いて下式から求める.

$$
\phi=\tan ^{-1} \sqrt[4]{\frac{D_{y}}{11 D_{x}}}
$$

また, ๆはせん断座屈から張力場への移行に伴う座屈波形の角度変 化を表す係数であり，文献 14 に基づき $\phi=1.48$ として与える. 


\section{3 剛性式および耐力式と実験結果の対応}

端部崩壊挙動の実験值（表 4) と剛性式および而力式から求めた 計算值との対応を表 6 に示寸. ${ }_{e} K /{ }_{c} K,{ }_{e} P_{y} /{ }_{c} P_{1 y},{ }_{e} P_{\max } /{ }_{c} P_{1}$ の実験值 $/$ 計 算值について, 平均はそれぞれ $1.14,1.26,1.19$, 変動係数はそれ ぞれ $0.12 ， 0.15 ， 0.16$ であり, 各式は実験結果に対して妥当な評価 結果を与えている。評価結果に対する載荷履歴の影響はほとんどな く, 単調載荷試験に基づく剛性式および耐力式が, 繰返し載荷試験 結果に適用できることが分かる.

張力場挙動の実験值（表 5）と剛性式および耐力式から求めた計

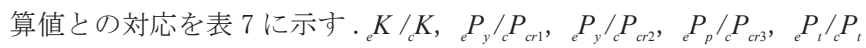
の実験值 / 計算值について, 平均はそれぞれ 0.98,0.89,0.91，0.99， 0.86 , 変動係数はそれぞれ $0.06,0.10 ， 0.07 ， 0.09 ， 0.12$ であり, 各式は実験結果に良好に対応している。ここで, 繰返し載荷におけ る張力場耐力実験值 $P_{t}$ は, 単調載荷のものより $5 \sim 20 \%$ 程度低下し ているため, ${ }_{e} P_{t} / P_{t}$ の比率も同様に低下している.この影響により, 張力場については, 計算値が実験值より若干大きくなる傾向にある が, 単調載荷試験に基づく剛性式および耐力式は, 繰返し載荷試験 結果に対し概ね妥当な評価を与えることが分かる。

\section{6. 波形鋼板の繰返し履歴特性に対するエネルギ一吸収性能の評価}

5 章で繰返し変形挙動に対する適用性を検証した剛性式および耐 力式に基づき, 端部崩壊挙動および張力場挙動の繰返し履歴のモデ ル化を行い, エネルギー吸収性能の評価を試みる。

\section{1 端部崩壊挙動の繰返し履歴モデル}

4.1 節で述べたように, 端部崩壊による繰返し変形性状は, 断面 のゆがみを伴う弾性的な変形挙動と, 山部が倒れ込みながら降伏す るスウェイのモードによる塑性崩壊挙動により特徵付けられる. 塑 性域では, $P_{\text {max }}$ に到達する変形域までは $P-\gamma$ 関係は紡錘形の安定し た履歴曲線を描く. 一方, 最大耐力 ${ }_{e} P_{\text {max }}$ に到達した後の変形域では, スウェイのモードにウェブのクリップリングと下フランジの局所的 な張力場形成が連成した複合的な抵抗モードに移行し, 履歴曲線が 瘦せ細る傾向を示している。ここでは, 山部を長方形断面とした試 験体において, 履歴が瘦せても耐力劣化は概ね降伏耐力実験值 $P_{y}$ の 荷重域で留まったことを考慮し, 降伏耐力計算值 $P_{1 y}$ を基本とした 図 10 のバイリニア型の繰返し履歴モデルを仮定する.このモデルは 以下の手順による .

(1)荷重ゼロの点 $\mathrm{O}$ と降伏耐力 ${ }_{c} P_{\mathrm{ly}}$ (式 (6)) となる点 $\mathrm{A}$ を結ぶ初期 剛性 ${ }_{c} K$ (式 (1)) の直線

(2)点 $\mathrm{A}$ から点 $\mathrm{B}$ に伸びる二次剛性 $K_{e}$ の直線

(3)点 B から $2_{c} P_{1 y}$ の荷重差となる点 $\mathrm{C}$ に伸びる剛性 ${ }_{c} K$ の直線

ここで, 二次剛性 $K_{e}$ の勾配は, 実験で得られた $P-\gamma$ 関係と履歴モ デルの対応から， $K$ の $5 \%$ として与えた .

\section{2 張力場挙動の繰返し履歴モデル}

4.2 節で述べたように, 張力場挙動の繰返し履歴は, 棚状域の形成, 前履歴サイクルで発現した張力場の再形成による耐力上昇, 初期剛 性より小さくなる傾向を示寸除荷剛性により特徴付けられる.ここ では, 文献 18 で提案されている平板のせん断座屈後繰返し履歴特性 を参考に, 図 11 に示す履歴モデルを仮定する.このモデルは, 図 12 の履歴曲線に示寸 (1) 除荷剛性 $K_{e} K_{t}$ の勾配となる除荷域, (2) 棚 状耐力 $P_{s}$ を一定に保つ棚状域, (3) 張力場再形成開始点 $\gamma_{s t}$ から耐

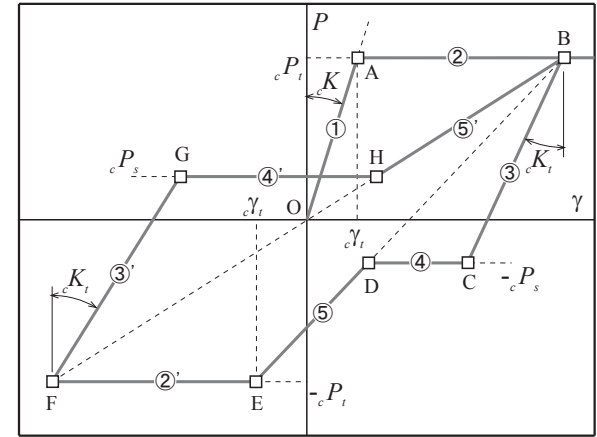

図 11 張力場挙動の繰返し履歴モデル

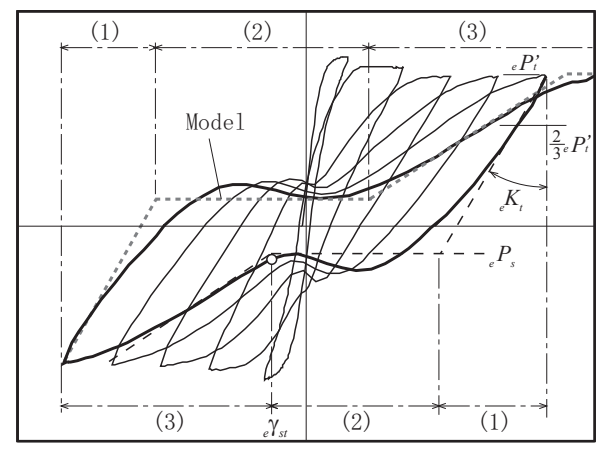

図 12 張力場挙動の履歴特性の抽出

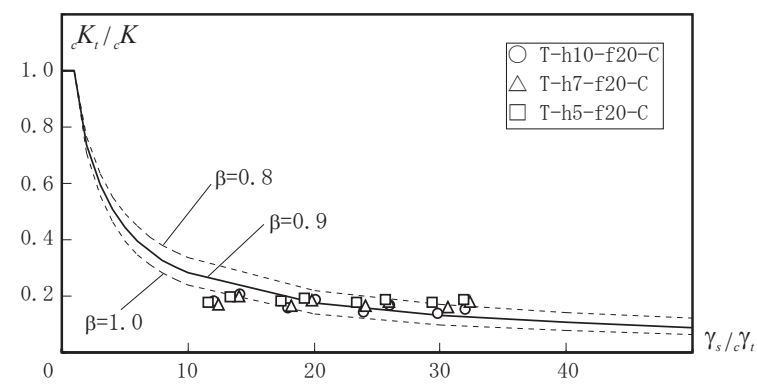

図 13 除荷剛性と係数 $\beta$ の関係

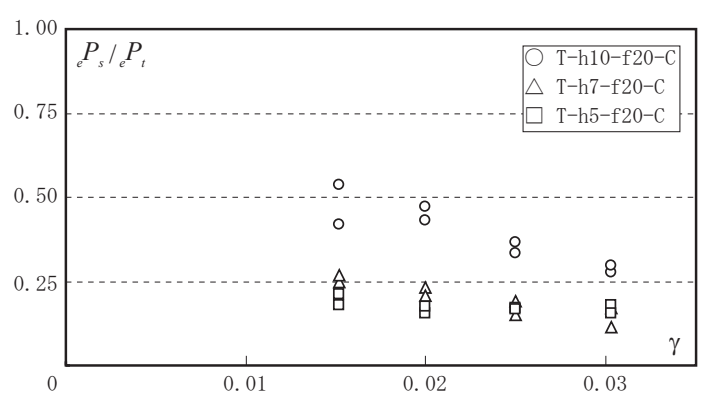

図 14 棚状耐力

力上昇し張力場耐力を保つ張力場域，の特性を抽出したものであり， 以下の手順による。

(1)荷重ゼロの点 $\mathrm{O}$ と張力場耐力 $P_{c}\left(\right.$ 式 (11) ) となる点 $\mathrm{A}\left({ }_{c} \gamma_{t},{ }_{c} P_{t}\right)$ を結ぶ初期岡性 ${ }_{c} K$ (式 (1)) の直線

(2)点 $\mathrm{A}$ から除荷開始点 $\mathrm{B}$ に伸びる $P_{t}$ で耐力一定の直線

(3)点 $\mathrm{B}$ と棚状耐力 $-P_{s}$ の荷重となる点 $\mathrm{C}$ を結ぶ除荷剛性 $K_{t}$ の直線 (4)点 $\mathrm{C}$ から張力場再形成開始点 $\mathrm{D}$ に伸びる $-P$ 、゙耐力一定の直線 (5)正負最大経験変位点を結ぶ線分に沿い $-P_{s}$ から $-P_{t}$ に変化する直線 
除荷剛性 ${ }_{c} K_{t}$ は張力場の発達程度により影響を受ける ${ }^{19)}$ と仮定し, ${ }_{c} K_{t}$ と ${ }_{c} K$ の関係を文献 18 と同様に次式で与える.

$$
\frac{{ }_{c} K_{t}}{{ }_{c} K}=1-\tanh \left(\beta \cdot \log \frac{\gamma_{s}}{{ }_{c} \gamma_{t}}\right)
$$

ここで, $\gamma_{s}$ : 骨格曲線としての変形角, ${ }_{c} \gamma_{t}:{ }_{c} P_{t}$ を ${ }_{c} K$ で除して得られ る変形角, である。係数 $\beta(=0.9)$ は, 図 13 に示寸各試験体の履歴 曲線から求めた実験除荷剛性 $K_{t}$ (図 12 : 除荷前耐力 $P_{e}^{\prime}{ }_{t}^{\prime}$ から $1 / 3$ 荷 重除荷した時点の割線剛性として定義）と式（13）の対応の平均值と して定めた。なお， ${ }_{c} K_{t} /{ }_{c} K$ は $\gamma_{s} / \gamma_{c}$ が変化しても概ね 0.2 の值である ため, $K_{t} /{ }_{c} K$ を一定值 $(=0.2)$ として評価することもできると考えるが, ここでは文献 18 の考えに従い式 (13) を採用している.

棚状耐力実験值 $P_{e}$ (図 12 : 各履歴ループの棚状域で絶対值が最小 となる荷重として定義）と変形角の関係を図 14 に示す. 棚状耐力は 変形の進展により, 張力場耐力 $P_{t}$ の $1 / 2 \sim 1 / 5$ 程度の範囲で漸減し ている.この耐力変化の比率の平均值が約 0.25 となることを考慮し, 棚状耐力 $P_{c}$ を次式により与える.

$$
{ }_{c} P_{s}={ }_{c} P_{t} / 4
$$

\section{3 繰返し履歴モデルと実験結果の対応}

端部崩壊挙動の履歴モデル（図 10）および張力場挙動の履歴モデ ル（図 11）と, シリーズ I およびシリーズ II の $P-\gamma$ 関係の対応を, それぞれ図 15 および図 16 に示す。また，履歴モデルによるエネル ギー吸収性能の評価結果を，それぞれ図 17 および図 18 に示す。

\section{3. 1 履歴モデルによる端部崩壊挙動の評価}

耐力劣化と履歴曲線が瘦せ細る傾向が小さく, 安定したエネルギー 吸収性能を発揮した，山部が長方形断面の E-h20-f40-C（図 15(a)) およびE-h15-f40-C（図 15(c)）については, 履歴モデルが実験結果 と妥当に対応している. エネルギー吸収性能についても, 図 17 (a) および図 17 (c) に示すように, 良好な評価結果を与えている.

一方, 耐力劣化と履歴曲線が瘦せ細る傾向を強く示した, 上フラ ンジ幅の狭い山部が台形断面の E-h20-f25-C (図 15(b)) については, $\gamma= \pm 1 / 66$ 以降のループで履歴モデルが $P-\gamma$ 関係を過大に評価し, 図 17 (b) に示すエネルギー吸収量についても実験值より大きな評価值 を与える傾向を示している。

以上のように, 図 10 の繰返し履歴モデルは山部を長方形断面とし た波形鋼板パネルに対応し, 上フランジ幅 $f$ に対する山高さ $h$ の比 $h / f=1 / 2.7 \sim 1 / 2(15 / 40 \sim 20 / 40)$ の範囲での適用性が確認できた.

\section{3. 2 履歴モデルによる張力場挙動の評価}

後座屈耐力から張力場域への耐力変化が小さい $\mathrm{T}-\mathrm{h} 7-\mathrm{f} 20-\mathrm{C}$ (図 16 (b) ) については, 履歴モデルが実験結果と良好に対応している. エ ネルギー吸収性能についても, 図 18(b) に示すように, 妥当な評価 結果を与えている.

一方, 後座屈耐力から張力場域一の移行過程で大きく耐力劣化す る T-h10-f20-C（図 16 (a)） では, 初期のループで履歴モデルが $P-\gamma$ 関係を下回り, 張力場形成後の棚状域でも同様の傾向が見られる. この結果，図 18 (a) に示寸エネルギー吸収量の評価において, 計算 值が実験值より小さくなる傾向を示している。

また, 後座屈耐力から張力場域一移行してからの耐力上昇が顕著 であった T-h5-f20-C（図 16(c)）では，初期のループで $P-\gamma$ 関係が 履歴モデルを下回り, 変形の進展に伴い徐々に荷重増加していくが, $\gamma=0.03 \mathrm{rad}$ 程度でも $P-\gamma$ 関係が履歴モデルを下回っている.このため, 図 18 (c) に示すエネルギー吸収量の評価において, 計算值が実験值 より大きくなる傾向を示している。

以上のように, 図 11 の履歴モデルは, 後座屈耐力と張力場耐力が 同等（表 2 の耐力比では ${ }_{c} P_{c r 3} /{ }_{c} P_{t}=0.94 ）$ の波形鋼板パネルに対応す ることが確認できた.

\section{7. まとめ}

本研究では，波形鋼板の端部崩壊挙動および張力場挙動に焦点を 当て, 載荷履歴とパネル断面形状を実験変数としたせん断試験によ り, 繰返し面内せん断力に対する波形鋼板パネルの弾塑性変形挙動 を明らかにした。試験結果の評価から，単調載荷試験に基づき導出 した剛性式および耐力式が，繰返し変形挙動に対して妥当に対応す ることを検証した。さらに，これらの評価式に基づく履歴モデルを 提案し, 繰返し変形挙動に対して良好なエネルギー吸収性能の評価 を与えることを確認した。ここで得られた知見を以下に示す。

1）繰返し載荷に対する端部崩壊挙動として，単調載荷時と同様 に, 山部が倒れ込みながら降伏するスウェイのモードが観察され た，せん断力の載荷方向が逆転しても端部崩壊挙動は繰返して発 現し, 変形の正負が切り替わる時点では山部の断面は変形前と同 様の形状に戻った．最大耐力を発揮した変形域までは紡錘形の安 定した履歴ループを描き，その後は，ウェブが局所的に折れ曲が るクリップリングおよび下フランジの局所的な張力場が連成する 複合的な抵抗モードへと移行して耐力劣化し, 履歴ループが徐々 に瘦せ細る傾向を示した。

2）端部崩壊挙動において, 耐力劣化と履歴曲線の瘦せ細る傾向を抑 えた安定した履歴曲線を得るには，波形鋼板パネルの山部の断面 形状を長方形と寸ることで， ウェブのクリップリングと下フラン ジの張力場形成が連成する複合的な抵抗モードへの移行を抑え， 剛性と耐力を山高さで設計する手法が有効である.

3）繰返し載荷に対する張力場挙動として, 単調載荷時と同様に, せ ん断座屈で発生したしわが引き伸ばされて降伏するモードが観察 された．せん断力の載荷方向が逆転しても張力場挙動は繰返し発 現するが，変形の正負が切り替わる時点でパネルが引き伸ばされ た変形がしわとして残留し, 張力場耐力より低い一定耐力を維持 したまま変形が進む棚状域が形成された。棚状域から更に変形を 進めると, ある変形角を境に棚状部分から耐力を再び上昇させな がら張力場を再形成し, 最大経験変位点近傍で前履歴サイクルの 延長線に沿って変形曲線を描いた。また，除荷剛性は初期剛性よ り小さくなる傾向を示し，変位振幅によらず初期剛性の概ね 0.2 倍程度となった。

4）張力場挙動において, 安定した履歴曲線を得るには, 山高さで後 座屈耐力と張力場耐力が同等になるように制御し，座屈後の耐力 劣化および変形進展時の耐力上昇を抑えるという手法が有効であ る.

5）繰返し載荷試験の実験值は，単調載荷試験に基づき導出した剛性 式および而力式に基づく計算值により妥当に評価できる。端部崩 壊挙動については, 初期剛性, 降伏耐力, 最大耐力について実験 值 / 計算值の平均がそれぞれ 1.14，1.26，1.19 であった。また, 張力場挙動については, 初期剛性, 弾性座屈耐力, 後座屈耐力, 


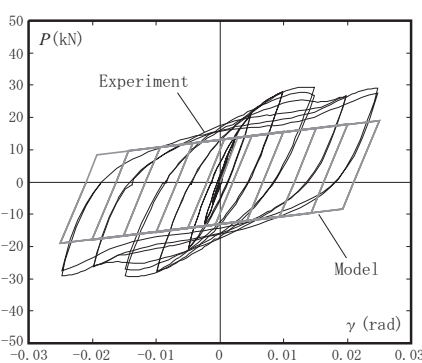

(a) $\mathrm{E}-\mathrm{h} 20-\mathrm{f} 40-\mathrm{C}$

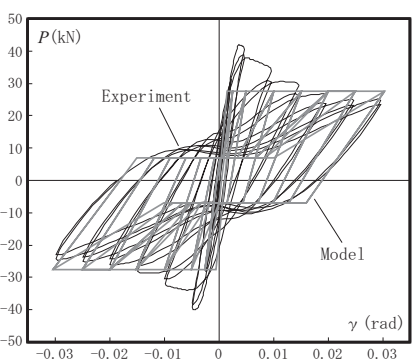

(a) $\mathrm{T}-\mathrm{h} 10-\mathrm{f} 20-\mathrm{C}$

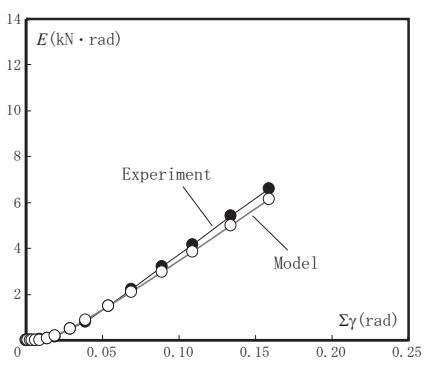

(a) $\mathrm{E}-\mathrm{h} 20-\mathrm{f} 40-\mathrm{C}$

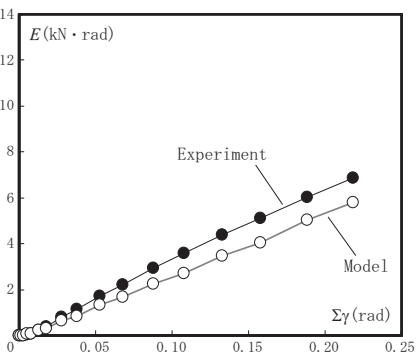

(a) $\mathrm{T}-\mathrm{h} 10-\mathrm{f} 20-\mathrm{C}$
図 17 履歴モデルによるエネルギー吸収性能の評価（シリーズ I )

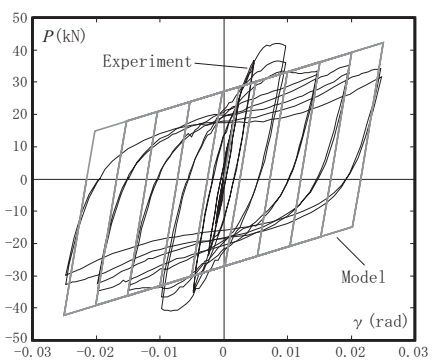

(b) $\mathrm{E}-\mathrm{h} 20-\mathrm{f} 25-\mathrm{C}$

図 15 履歴モデル - と $P-\gamma$ 関係の対応 (シリーズ I )

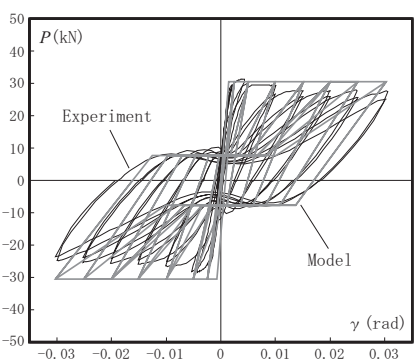

(b) $\mathrm{T}-\mathrm{h} 7-\mathrm{f} 20-\mathrm{C}$

図 16 履歴モデル - と $P-\gamma$ 関係の対応（シリーズ II）

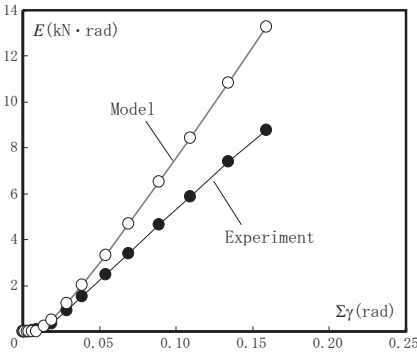

(b) $\mathrm{E}-\mathrm{h} 20-\mathrm{f} 25-\mathrm{C}$

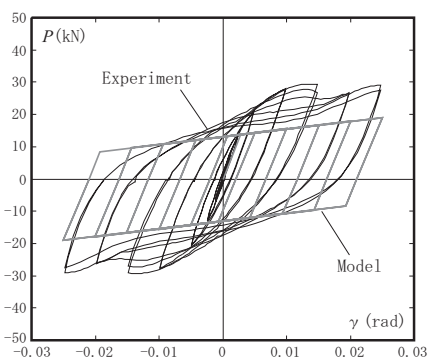

(c) $\mathrm{E}-\mathrm{h} 15-\mathrm{f} 40-\mathrm{C}$

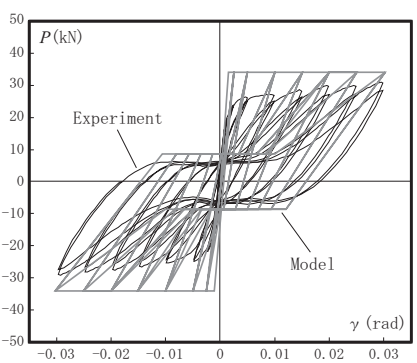

(c) $\mathrm{T}-\mathrm{h} 5-\mathrm{f} 20-\mathrm{C}$

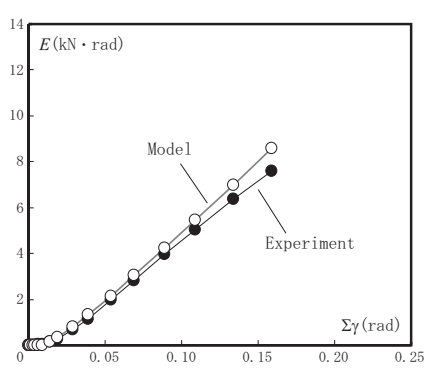

(c) E-h15-f40-C

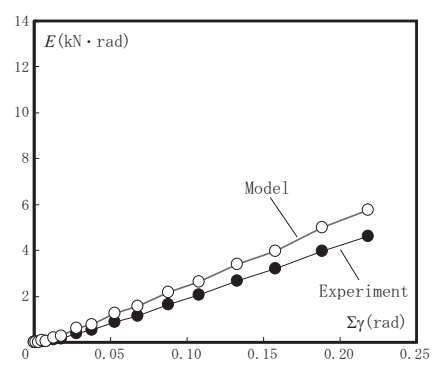

(c) $\mathrm{T}-\mathrm{h} 5-\mathrm{f} 20-\mathrm{C}$

図 18 履歴モデルによるエネルギー吸収性能の評価（シリーズ II）

張力場耐力について実験值 / 計算值の平均がそれぞれ 0.98, 0.90, 0.99, 0.86 であった。

6）端部崩壊の弾塑性変形挙動を, 山部の断面のゆがみを考慮した 弾性剛性, スウェイのモードによる端部崩壊耐力に基づくバイリ ニア型の繰返し履歴でモデル化した．このモデルは, 山部を長方 形断面とした波形鋼板パネルの $P-\gamma$ 関係と妥当に対応し, エネル ギー吸収性能についても良好な評価を与えた。

7）張力場の弾塑性変形挙動を, 張力場域の耐力, 棚状域の耐力, 棚 状域から張力場域一の耐力上昇, 初期剛性および除荷剛性に基づ く繰返し履歴でモデル化した.このモデルは, 後座屈耐力と張力
場耐力が同等となる山高さとした波形鋼板パネルの $P-\gamma$ 関係と良 好に対応し, エネルギー吸収性能についても妥当な評価を与えた。 6.1 節の端部崩壊挙動の履歴モデル（図 10）については, 異なる 形状範囲での適用性確認, また, 山部を台形断面としたパネルへ対 応する履歷モデルの検討が今後の課題である. また, 6.2 節の張力 場挙動の履歴モデル（図 11）については, 履歴モデルが対応する耐 力比範囲の確認, また, 後座屈耐力から張力場耐力への耐力変化の 影響を考慮した評価手法の検討が今後の課題である. 


\section{参考文献}

1) European Recommendations for the Application of Metal Sheeting acting as a Diaphragm, European Convention for Construction Steelwork, 1995

2) Diaphragm Design Manual Third Edition, Steel Deck Institute, 2004.9

3）麻生直木 他: 波形鋼板耐震壁の力学性状に関する研究（その 1 ～）, 日 本建築学会大会学術講演梗概集, C-1, pp. 1123-1126, 2006.9

4) 池田崇 他: 波形鋼板耐震壁の力学性状に関寸る研究（その $3 \sim 5$ ), 日本 建築学会大会学術講演梗概集, C-1, pp. 1121-1126, 2007.8

5）田中浩史，河合良道 : 折板を面材に用いたスチールハウス用耐力壁の面内 せん断実験, 日本建築学会大会学術講演梗概集 C-I, pp. 837-838, 2009.8

6) S. Tipping, B. Stojadinovic: Innovative Corrugated Steel Shear Walls for Multi-story Residential Buildings, The 14th World Conference on Earthquake Engineering, 2008. 10

7)H. S. Essa, R. Tremblay, C. A. Rogers: Behavior of Roof Deck Diaphragms under Quasistatic Cyclic Loading, Journal of Structural Engineering, ASCE, pp. 1658-1666, 2003. 12

8) J. T. Easlay: Buckling Formulas for Corrugated Metal Shear Diaphragm, Proc. A. S. C.E. , J. Struc. Div., pp. 1403-1417, 1975. 7

9）五十嵐規矩夫, 藤澤逸志, 清水信孝 : 矩形形状を有する波形鋼板のせ 几断弾性座屈耐力評価, 日本建築学会構造系論文集, 第 73 巻, N0.632, pp. 1883-1890, 2008. 10

10) J.M. Davies, J.Fisher: End failure in stressed skin diaphragms, Proc. Instn Civ. Engrs, Part2, pp. 275-293, 1987. 3

11）清水信孝, 五十嵐規矩夫 : 面内せ九断力を受ける波形鋼板の端部崩壊挙動 に関する研究, 日本建築学会構造系論文集, 第 74 巻, N0.645, pp. 21192126, 2009. 11

12) J.M. Davies, E. R. Bryan : Manual of Stressed Skin Diaphragm Design, 1982

13) C. A. Rogers, R. Tremblay: Inelastic seismic response of frame fasteners for steel roof deck diaphragms, Journal of Structural Engineering, ASCE, 129(12), pp. 1647-1657, 2003

14）清水信孝, 岡田忠義, 五十嵐規矩夫 : 波形鋼板パネルのせん断座屈後挙動 に関する研究, 日本建築学会構造系論文集, 第 75 巻, N0.651, pp. 10131020, 2010.5
15)E. R. Bryan, P. Jackson: The Shear Behavior of Corrugated Steel Sheeting, Thin walled Steel Structures Their Design and Use in Building, pp. 258-274, 1967.9

16）木村衛, 井上哲郎 他: 薄板の座屈後耐力, 日本建築学会構造系論文集, 第 545 号, pp. 135-140, 2001. 7

17) H. Wagner: Flat sheet metal girder with very thin metal web, Part I. General theories and assumptions. Technical memorandum no.604, NACA, Washington, DC, 1931

18）五十嵐規矩夫，清水真，富澤徹弥：H 形鋼ウェブ薄板のせん断座屈後繰返 乙履歴特性，日本建築学会構造系論文集，第 612 巻，pp. 197-205，2007.2

19) P. Kuhn: Strength Analysis of Stiffened Beam Webs, NACA, TN1364, pp. 1-61, 1947. 7

20）岩本いづみ，木村衛，小河利行：薄板要素のリップ補剛効果に関する研 究 座屈後耐力について, 日本建築学会構造系論文集, 第 548 巻, pp. 153158, 2001. 10

21）岡田久志，橋本篤秀，緑川光正 : 金属系新素材・新材料の利用技術の開発 （建設省総合プロジェクト・新素材）その 66 「一様圧縮力を受ける制振鋼 板の座屈強度・後座屈強度」, 日本建築学会大会学術講演梗概集, 構造 (2), pp. 1331-1332, 1992.8

22）座屈設計ガイドライン，社団法人土木学会, pp. 161-233, 1987. 10

23）金箱温春，小河利行，竹内徹，松原洋介：せん断力を受ける部分支持され た薄鋼板の座屈耐力及び座屈後耐力の評価, 日本建築学会構造系論文集, 第 610 巻, pp. 185-190, 2006. 12

注

注 1）座屈後挙動の耐力を表す用語として「座屈後耐力」を用いることが多い が, この用語は弾性座屈後の耐力上昇 ${ }^{16)}, 20$ なとおよび座屈後の張力場形成 23)抾のいずれの挙動に対しても使用されている. 本論においても, これ ら両者を含む一連の挙動を「座屈後挙動」の用語で表している.ただし， 弾性座屈後の耐力上昇による耐力を「後座屈耐力」（文献 21 および 22 の 「後座屈」の表現を参考), 張力場形成による耐力を「張力場耐力」として, 両者を明確に区別することとした。

(2010年 3 月 9 日原稿受理, 2010年 6 月 7 日採用決定) 